\title{
Coalitions of the willing? \\ International backing and British public support for military action
}

\author{
Robert Johns* \\ University of Essex
}

and

\author{
Graeme A. M. Davies \\ University of Leeds \\ * Corresponding author \\ Department of Government, University of Essex, \\ Wivenhoe Park, Colchester CO4 3SQ, U.K. \\ Tel: (+44) 1206872508 \\ E-mail: rajohn@essex.ac.uk
}

Paper to be presented at a seminar on «Opinion publique et Politique étrangère » at Sciences Po Grenoble, France, 22 November 2013

Acknowledgements

The data analysed in this article come from surveys funded by the Economic and Social Research Council (RES-062-23-1952) as part of a project to investigate 'Foreign policy attitudes and support for war among the British public'. We gratefully acknowledge the Council's support, and the support and advice we received from colleagues in designing the surveys. 
Studies of public support for war highlight the importance of context. Most people do not simply support or oppose the use of force but instead assess its merits depending on various aspects of the situation. One such aspect is the extent of international backing - whether from individual states or supranational organisations - for military action. This backing may be 'active', notably through the contribution of troops, or more 'passive', through the endorsement or authorisation of action. In this article, a survey experiment, embedded in a major internet survey of British foreign policy attitudes $(\mathrm{N}=2,205)$, is used to explore how international backing affects public support for military action. Britain's military potential and recent history make it an obvious case study here. Both 'active' and 'passive' backing prove to have separate and significant positive effects on support. Importantly, the absolute number of troops involved matters far less than the proportion of total troop numbers to be contributed. And the perceived strength of the enemy predicts support only when the British are to contribute a large proportion of total forces. Predispositional variables are used to investigate the sources of the experimental effects but with little success: the impact of international backing proves remarkably consistent across the sample.

Recent debates about possible Western military action in Libya and Syria were dominated by the question of the breadth of the international coalition needed to legitimise such action, with heavy emphasis on the need to obtain UN Security Council resolutions authorising intervention. In Britain as elsewhere, the background - indeed, the foreground - to those debates was the Iraq war, in which the UK was junior partner to the US in a 'coalition of the willing' that took action without explicit UN authorisation and in the face of considerable international opposition. This was an example of the brand of 'liberal internationalism' pursued by former Prime Minister Tony Blair in which military intervention on humanitarian grounds was deemed justified even in the absence of authorisation from international organisations. That doctrine in general, and its application in Iraq in particular, have come under close scrutiny. Meanwhile, British forces have been in Afghanistan for over a decade as part of a NATO mission which has seen simmering disagreements about whether some allies are not shouldering their fair share of the military burden. In short, the nature and extent of international support is a prominent element in elite debates about military action, in Britain as elsewhere. 
This article is about whether and how British public support for war is also influenced by the international backing for military action. Numerous academic studies have demonstrated the importance of public backing to governments considering the use of force (e.g. Gartzke, 2000; Kadera et al., 2003; Reiter, 2003; Sullivan, 2008), and popular support or the lack of it - has been a prominent topic in elite discussion and media coverage of the Afghanistan and Iraq conflicts. So this question about mass opinion is well worth asking. It is also worth asking about publics beyond the US, where the large majority of academic research on public support for war has been conducted. The US is obviously atypical in its capacity for unilateral action and so it is useful to broaden the evidence base to a country like Britain which, while retaining the potential for acting alone, is more obviously in need of international backing.

There is another important respect in which we advance the literature in this field. Previous work on international backing has tended to blur or neglect the distinction between 'passive' support - that is, some kind of endorsement of the use of force - and 'active' support in the form of a tangible contribution to military action. Existing research cannot readily indicate which of these weighs heavier in public judgements about military action, and whether there are inidividual differences in that relative importance. By addressing those issues, we gain insight into whether international support matters more because of its legitimising effects or more because it increases the chances of success and minimises the costs - for instance, in terms of casualties - of action.

Our primary means of addressing these questions is a survey experiment in which we manipulate the degree of international backing and record the effects on support for the use of force. The experimental approach is increasingly used in this broader field but has only recently featured in the specific literature on international backing and support for war (Brooks and Valentino, 2011). We begin by reviewing that literature, identifying the reasons 
why - and conditions under which - we would expect international support to translate into public support. Having set out the data, measures and experimental design to be used, we report results showing that the British public is broadly multilateralist and that even those sceptical about military action can be persuaded to support it as part of a wider force. We conclude by discussing the validity and implications of our findings.

\section{International backing and public support for war}

One prominent strand of research into public support for war has been concerned with individuals' predispositions to support military action. Scholars have specified a range of values and ideological principles that citizens can use to lead them to decisions on foreign policy issues. Prominent among these ideological dimensions are internationalism versus isolationism (Wittkopf, 1990), militarism versus accommodation (Holsti, 2004; Alvarez \& Brehm, 2002, ch. 9), national chauvinism (Herrmann et al., 2009) and broader political ideology (Russett et al., 1994). While most of this research has been based on the US public, there seems no reason to doubt that the basic point holds in Britain and elsewhere. Core beliefs and values leave some people strongly predisposed against military action, but others far readier to support the use of force.

However, predispositions are only part of the story. Most people will endorse the use of force in certain circumstances but not in others. Public opinion researchers have largely ceased to regard such 'inconsistency' as evidence of nonattitudes (see Almond, 1950; Converse, 1964). Rather, it demonstrates the sensitivity of public opinion to context (Zaller, 1992; Alvarez \& Brehm, 2002). A vast range of specific contextual or situational factors can affect public support for military action, both initially - at the outset of the war - and as the conflict progresses. Examples include the objective of military action (Jentleson, 1992; Oneal et al., 1996), the extent of domestic elite consensus (Zaller, 1992; Dixon, 2000), casualty 
rates (Gartner \& Segura, 1998; Karol \& Miguel, 2007), and the extent of international backing, from other states or supranational organisations (Kull \& Destler, 1999; Holsti, 2004; Smith, 2005).

The last of these is our central focus in this article. There are several reasons why international support for a military intervention might translate into greater public support, and the relative importance of these depends on whether that international backing comes from supranational bodies or from one or more other single-actor states. A first possibility, suggested by Isernia and Everts $(2004,253)$, is 'that over the years people have internalised, as it were, the rules of international law' - which prohibit the use of force unless in selfdefence or with the authorization of the UN Security Council. Few citizens are likely to know the precise legal position but many more will have grasped that unilateral action is less legitimate. Applying a "domestic analogy" would lead to a similar conclusion, unilateral action failing to meet democratic criteria of deliberation and consent (Russett, 1993). These points apply particularly to the authorisation of force by international organisations but, even if this is lacking, support from other states - in 'coalitions of the willing' - can also boost public approval. In particular, this support serves as a heuristic for judging the extrinsic characteristics of a military intervention, notably its justifiability and effectiveness. Difficulties in attracting international support are likely to spark public doubt not only about the success of any military campaign but also about the worthiness of the cause.

The distinction between supranational and multi-national support cross-cuts another important distinction, between what might be called 'passive' (or 'moral') and 'active' support. In the case of other states, this amounts to the difference between words - statements endorsing the use of force - and deeds. Those deeds could take many forms - financial backing, permission to use air space, sending in troops, and so on - and, since some of these seem rather more 'active' than others, the passive-active variable is perhaps more of a 
continuum than a dichotomy. With supranational organisations, meanwhile, the words-deeds distinction is blurred: a UN Security Council Resolution represents more active backing than support from an individual country. Nonetheless, the nature of backing provided by, say, the UN or NATO can be located along the same continuum.

The passive-active distinction has been underplayed in the existing literature. One exception is Eichenberg's (2006) major cross-national analysis of polling data which showed that support for military intervention was boosted by both 'the endorsement of the international community through formal mandates and the deployment of international forces' (p. 56). We build on that basic finding, not only by bringing individual-level data to bear on the matter but also looking in more detail at the relative importance of the two types of support, at whether they operate additively or in interaction, and at the different signals that they might send to domestic citizens. Passive support is a stronger cue about the justification than about the effectiveness of the use of force; the reverse is true of active support. ${ }^{1}$

In these areas, as in most spheres of foreign policy opinion, it is the US public that has been most thoroughly surveyed. Yet this is anything but a typical case. Since the USA's military power and global role give it unparalleled capacity to act unilaterally, we might expect international backing not to weigh heavily in its citizens' judgements about military action. It is therefore striking that the US public in fact takes a strongly multilateral view of the use of force. ${ }^{2}$ The results of a 1998 survey, in which only $23 \%$ of respondents said that 'in international crises the United States should 'take action alone' it if does not have the support of its allies' (Page \& Barabas, 2000, 358), are illustrative of a more general rejection of

\footnotetext{
${ }^{1}$ Although they deal only with passive support in the form of UN approval, Brooks and Valentino's (2011) intriguing results are at least indirectly relevant here. They find that the usual gender gap in support for military action is eliminated, even reversed, in the case of force endorsed by the UN. Since those authors' broader case is that, compared to men's, women's support for war is driven more by ethical and less by strategic considerations, they effectively make the same argument: that passive support is more about legitimising military action than about improving its chances of success.

${ }^{2}$ The extent of this multilateralism is underestimated by elites (Kull \& Destler, 1999) and even by the public itself (Todorov \& Mandisodza, 2004).
} 
unilateral action (Holsti, 2004; Kull \& Destler, 1999). International backing is valued particularly when it comes from supranational organisations. Chapman and Reiter (2004) find that "rally-round-the-flag" effects are stronger where the UN Security Council has sanctioned military action, but also that public approval is not necessarily boosted by a multilateral approach in the absence of Security Council support. This is consistent with surveys showing strong support for the UN and NATO, including widespread willingness to participate in peacekeeping operations under the auspices of those organisations (Kull \& Destler, 1999; Page \& Barabas, 2000). Beyond the military context, there is broader US public support for burden-sharing with other nations. As Todorov and Mandisodza note: 'in the last seven years the group of Americans who think that the United States should do its fair share in solving international problems has been more than four times larger than the group of Americans who think that the United States should be the preeminent world leader in solving such problems' (2004, 343; see also Kull \& Destler, 1999).

To date, there has been no systematic study of the impact of international backing on British popular support for war. But existing evidence bearing on this issue points to a British public that is still more multilateralist than its US counterpart. This difference between the two countries is predictable given Britain's much more limited capacity for acting alone. ${ }^{3}$ If the difference is also rather narrow then this has more to do with the perhaps surprisingly multilateral approach of the US public than with any strong strain of unilateralism in Britain. The 2002 Transatlantic Trends project included both survey questions and an embedded experiment concerning possible action in Iraq and, in both cases, 'the legitimacy conferred by a UN mandate had an even greater importance for the British public than for the French or German respondents' (Isernia \& Everts, 2004, 249). In a later (2008) survey reported by

\footnotetext{
${ }^{3}$ A game-theoretic approach could lead to the opposite conclusion about the effect of a country's military strength in this context. The publics in smaller and less powerful states might reason that, if international support is plentiful, then the marginal benefit of their participation is minimal and hence exceeded by the costs. Put the other way round: 'if no one else is going to do something about this, then we'll have to'.
} 
Reifler et al. (2011), a majority of respondents agreed (and only a quarter disagreed) that "Britain should not use its armed forces abroad unless it gets approval from the United Nations". Such multilateral instincts also show up in longitudinal studies of mass support for war: Bronski and Way's (2003) analysis shows that in Britain, as in the US, the public is more inclined to rally round the flag in cases of joint military action. ${ }^{4}$ Finally, Younger (1964) suggests that, even in the decades following the Second World War, when the public might be expected to have been more confident in Britain's capacity to act alone, there was nonetheless widespread support for the UN and for general internationalism.

These consistently multilateral attitudes are noteworthy given that, twice in the last thirty years, British governments have taken what was basically unilateral action - in the Falkland Islands (in 1982) and in Sierra Leone (2000). Moreover, in the former case, the UN explicitly opposed that action. ${ }^{5}$ Yet both interventions were largely successful and the Falklands, in particular, enjoyed strong public support (Clarke et al., 1990; Price \& Sanders, 1993). If anything, it is more recent joint actions, especially those in Iraq and Afghanistan, whose justification and effectiveness has been called into question by the public. This is not necessarily out of line with the notion of a multilateralist British public. For one thing, as noted at the outset, much of the controversy over the Iraq War concerned the lack of support from the international community and the legal wrangling over whether action was UNauthorised. For another, it may be that those interventions enjoyed the 'wrong kind' of multilateral support. More specifically, the (dominant) presence of the US in those 'coalitions of the willing' may now send a less powerful signal about the likely effectiveness of action, and could even have a delegitimising effect. The speculative tone of this discussion reinforces the case for systematic analysis of the conditions under which international backing boosts

\footnotetext{
${ }^{4}$ Lai and Reiter (2005) are more inclined to equivocate on this point, probably because the limited number of cases for observation makes it difficult to draw firm conclusions.

${ }^{5}$ While the Security Council did pass a resolution calling on Argentina to withdraw from the Falklands, its resolution also called on both sides to seek a diplomatic resolution and to desist from further military action.
} 
British public support for military action. Such analysis needs not only to distinguish supranational organisations from other states as providers of support, but also to consider the particular impact of key potential allies.

In the upcoming methods section, we describe how the various aspects of international backing were operationalized. For now, we cast hypotheses in general terms. The first two are straightforward and concern the main dimensions of international support:

H1: The greater the international passive backing, the greater the public support for military action

H2: The greater the international active backing, the greater the public support for military action

The two dimensions are obviously related: contributions of troops and equipment will presumably only come from states or organisations that are committed to the cause, and the public might well expect that vocal backing for the use of force will translate into active contributions. Although our experimental method gives us some scope for enforcing the distinction, the likelihood of 'spillover' makes it difficult to predict the nature of any interaction between active and passive backing. Such interaction could be positive, the public deeming both necessary in order for a mission to be justified and likely to succeed, or negative, the public seeing little benefit in wider moral support provided that extensive active backing is available. Hence, while we can test for that interaction, we do not specify a directional hypothesis about its nature.

However, we do specify two further hypotheses about the impact of active backing. The first emphasises that public dissatisfaction at a lack of active support does not simply reflect strategic calculations about the greater risk to Britain's troops. There is also a normative point that the public is likely to resent having to do more than its perceived fair share (Smith, 2005, 500). It may therefore be that the public would prefer a mission in which 
a major deployment of British troops forms a small proportion of the total force over a mission in which, while the overall burden carried by the British is lighter, its share of the effort is greater. We therefore hypothesise:

H3: Public support depends more on Britain's relative than absolute contribution to military action

This is not to say that strategic considerations play no part in these judgements. There are a number of situational factors that seem likely to interact with international backing in shaping public support. Examples include the purpose of the war, the weight of national interests at stake, and the strength of the enemy. To avoid over-complicating the experimental design and losing statistical power, we were obliged to choose among these and we focus on the latter since it raises the particularly immediate question of the threat posed to British forces. The hypothesised interaction is:

H4: International backing has a greater impact on public support for military action when the adversary is stronger

\section{Who will go it alone? Predispositions and reactions to international backing}

Herrmann et al. (1999) use a series of survey experiments to demonstrate the impact of both predispositions and situational factors on the American public's support for military action. They also highlight the interaction between predispositions and context. In their 'cognitiveinteractionist' framework, the way that people respond to specific situations depends on their general values and attitudes. For instance, while respondents were on the whole readier to use force when US interests were clearly at stake, this difference was far greater among those scoring high on 'military assertiveness'; less militarist respondents remained reluctant to take action even it were definitely in the national interest $(1999,563)$. So we should bear in mind 
the likelihood that the British public will not react homogenously to our key variable, international backing, when considering military action.

A variety of predispositions are potentially relevant in this context. The first is the militarism variable mentioned in the example just above. Assuming that we see a similar pattern to that reported by Herrmann et al., then international backing would persuade those already disposed to consider the use of force but would not convert those sceptical about military action. (The reverse interaction would imply that militarists need no such persuasion but that international backing can temper pacifist instincts.) In line with a distinction drawn earlier, we examine two strands of militarist predispositions: whether the use of force is regarded as generally justifiable and as generally effective. This enables us to assess whether the different dimensions of international backing tend to convince citizens of the moral or of the practical case for military action.

Herrmann et al. (1999, 563-4) also found an interaction between internationalist predispositions and situational factors and the same seems likely here. We might expect internationalists to be especially responsive to the extent of foreign backing for action while, almost by definition, isolationists are unlikely to be coaxed into action overseas simply because other nations or supranational organisations are also involved. ${ }^{6}$ Admittedly, the interactive relationship here depends on which of the 'two faces' of internationalism is involved (Wittkopf, 1990; Holsti \& Rosenau, 1993). While militant internationalists may prefer their country to take action alone, it is cooperative internationalists who are more likely to be persuaded of the merits of military action if it wins cross-national or supranational backing.

The final set of predispositions that we examine is citizens' prior attitudes to those international actors that might lend support to military action. The more respect that people

\footnotetext{
${ }^{6}$ Or we might see a non-monotonic pattern, with international backing unnecessary for the committed internationalist, irrelevant to the resolute isolationist, but able to convince those in the middle of that continuum. We test for such curvilinearity but stick to the simpler hypothesis here.
} 
have for, say, the UN, the more likely it is that UN backing will convince them of the case for military action. This effect could result from quite detailed cognitive processing, as citizens update their judgements about the likely justification or effectiveness of military action based on their perceptions of the records, capacities and motivations of the international actors involved. Or it could be a very simple application of what Sniderman et al. (1991) call the 'likability heuristic': the mere association of military action with a disliked object is enough to turn someone against that action.

This leads us to a series of hypotheses about the moderating effect of the various predispositions:

H5: The impact of international backing on public support for military action is stronger on those...

a) generally predisposed to regard military action as justified

b) generally predisposed to regard action as effective

c) scoring higher on internationalism

d) favourably disposed towards the international actor giving passive support

\section{Methods, data and measures}

The main empirical basis for this study is a survey experiment. Using a design similar to that reported by Brooks and Valentino (2011), we presented respondents with a vignette concerning potential military action and aspects of that vignette - notably the degree of international backing for action - are manipulated. We describe the experiment in details shortly. It is first worth briefly noting the key advantage of an experimental design. This centres on internal validity and, specifically, the power of experimental control and random assignment to permit causal inference (Morton and Williams, 2008). Studies of aggregate opinion, investigating the covariation of public support and the degree of international 
backing, are useful (see especially Eichenberg, 2006) but suffer from a 'too many variables, too few cases' problem. Researchers not only lack control over other situational factors but are also unsure about whether and how the extent of international backing was perceived by the public.

An experiment also offers an external validity advantage over the alternative most prominent in the literature, namely the hypothetical survey question in which respondents are asked - either about military action in general or about a particular war - whether they would be more likely to approve of action were a given international actor to support it. Such a question is available in the survey analysed here and the responses provide a useful scenesetter in our results section. However, the strength and blatancy of the cues in such hypothetical questions means that they are liable to overstate effect sizes. Hence we turn to the experiment for a more valid test of our hypotheses. Of course, experiments come with their own external validity problems - a point to which we return in the concluding section and so it is advisable to take a multi-methods approach to research questions like these. Our study does not supplant but supplements previous research.

Data

This experiment was included in a major three-wave survey study of foreign policy attitudes among the British public. ${ }^{7}$ The surveys were fielded on the internet by YouGov, whose approximately 300,000 panel members formed the sampling frame. ${ }^{8}$ The company has an impressive track record of sampling and weighting to achieve representative samples of the

\footnotetext{
${ }^{7}$ These data are archived and available for replication studies at http://dataservice.ac.uk.

${ }^{8}$ Most of these are actively recruited (by targeted campaigns via non-political websites) rather than volunteering for the panel. Similarly, respondents are not able to choose in which surveys to take part: they are either sampled for a given data collection or not. Political surveys, especially those covering relatively esoteric issues like this one, are the exception rather than the rule for most panel members - much of YouGov's data collection is in the fields of market research or more general opinion polling. Respondents are paid small incentives for taking part, typically around $£ 1$ for surveys of 10-15 minutes like each wave of this study.
} 
British electorate - as measured by their accuracy in predicting election results. ${ }^{9}$ Several recent analyses of British foreign policy attitudes have been conducted using YouGov survey data (e.g. Reifler et al., 2011; Johns and Davies, 2012; Clements, 2013).

The study was not a traditional panel. The aim was rather to divide a long instrument into manageable chunks and to field these at brief intervals so that the entire process of data collection took less than a month. The key methodological details of the three waves of fieldwork are set out in Table I, which also indicates the waves from which the questions used in this article are taken. The core experiment was fielded in the second wave of data collection while the survey measures used come from various points in the survey.

\section{[Table I about here]}

Survey experiment and situational variables

The experimental vignette is presented in the form of a brief newspaper report. It refers to a country threatened by a more powerful neighbouring state and the issue at stake is whether Britain should send in troops to defend the country under threat. ${ }^{10}$ We follow the example of Herrmann et al. (1999) and Brooks and Valentino (2011) in referring to hypothetical rather than actual countries. The full vignette, with manipulations highlighted in bold, is below.

Next, here is a question about a situation in which Britain might take military action. Please read the following short newspaper story and then answer the question.

"Today the British government announced that it will send troops to Country A to defend it against threats from its larger neighbour, Country B. This mission, which has the support of the USA/the support of NATO/the support of the UN/yet to win any significant international support, will send 1,000/10,000 British servicemen and women to fight in the region. Other countries have been willing/unwilling to commit

\footnotetext{
${ }^{9}$ In a mode experiment fielded as part of the 2005 British Election Study, Sanders et al. (2007) showed that the covariance structures - and hence the conclusions about party choice and turnout - generated from a YouGov internet sample were not significantly different from those generated from a traditional face-to-face sample. ${ }^{10}$ As a case of aggressor restraint, this is the kind of scenario found by Jentleson (1992) to win strongest support (at least in the US public). This should be borne in mind when considering the overall level of approval for military action recorded in our experiment. It is also worth considering whether the moderating effect of international backing might be greater in certain scenarios. With that in mind, we avoided making any explicit reference to the threatened state being an ally of Britain, in case that implied such a strong ethical obligation to intervene that even those normally reluctant to act alone would feel compelled to do so (Smith, 2005, 495-6).
} 
forces and so British forces will make up $10 \% / 90 \%$ of the total troop numbers. According to Professor John Irving, a leading expert on the region, the potential invader Country B has a large and well-trained/small and not very well-trained military."

Four situational features of the story were thus subject to random manipulation: the extent of passive support (from the USA, NATO, the UN, or non-significant); active support, i.e. the proportion of total troop numbers contributed by Britain (10\% or $90 \%)$; troop numbers $(1,000$ or 10,000); and adversary strength (large and well-trained or small and not very well-trained military). The relative complexity of this $4 \times 2 \times 2 \times 2$ design means that the large total sample size (of well over 2,000) is particularly important. It also means that some of the experimental manipulations, having just two conditions, are rather unsubtle. In particular, we would ideally have been able to vary Britain's share of troop deployments beyond a simple 'nearly all' versus 'hardly any'. As it was, we sought roughly to replicate with percentages the extremes of the passive support variable - with Britain either fighting more or less alone or as part of a major international force - and thus to allow for at least broad comparison of the effects of passive and active support. For similar reasons, we specified two conditions for troop numbers that varied by roughly the same order of magnitude as the troop percentages. ${ }^{11}$

The newspaper story is followed by two questions - shown below - providing dependent variables for the upcoming analyses. The second question is included partly to force respondents to come down on one side of the fence and partly to provide a simple 'percentage support' figure to ease comparisons.

On a scale from 0 ('strongly oppose') to 6 ('strongly support'), how do you feel about the decision to send British troops to Country A?

$\square$ And if you had to choose 'oppose' or 'support', which would you go for?

Additional variables

\footnotetext{
${ }^{11}$ Another constraint on calibrating the manipulations was the need to avoid logical impossibilities. For example, we could not tell respondents that the mission enjoyed no international support whatsoever and then announce that Britain was contributing anything less than $100 \%$ of the fighting force.
} 
We hypothesised interactions between international backing and three predispositional variables: militarism, internationalism, and attitudes to international actors. As noted, we measure two variants of militarism, concerning the justification and effectiveness of military action:

$\square$ Next, some questions about the use of military force. The first asks: do you think the use of force can be morally justified? On a scale from 0 to 6 , where 0 means 'definitely cannot be justified' and 6 means 'definitely can be justified', which number best represents your view?

$\square$ In general, how effective do you think the use of military force is? On a scale from 0 to 6 , where 0 means 'not at all effective' and 6 means 'very effective', which number best represents your view about the use of force?

Internationalism is measured with a short battery of three Likert items using the standard five-point agree-disagree format. (Asterisked items are reverse-scored.) The items are adapted from measures used by Hurwitz and Peffley (1987).

$\square$ Britain shouldn't worry about world affairs but just concentrate on taking care of problems at home*

$\square$ Britain needs to play an active role in solving conflicts around the world

$\square$ Britain is too small a country to be out policing the world*

While an alpha coefficient of 0.71 means that this scale meets conventional reliability criteria, it does not allow us to distinguish cooperative from militant internationalism but is instead a more general measure of internationalist-isolationist orientations.

The questions measuring attitudes to the UN and NATO were worded as follows:

Thinking now about international organisations, how much respect - on a scale from 0 ('no respect at all') to 6 ('a great deal of respect') - do you have for the following?

The question measuring attitudes to the USA (among other countries) was slightly different

$\square$ Now we would like to know how you feel about particular countries these days. Please rate your feelings about each one on a scale from 0 to 6 , where 0 means you 'strongly dislike' and 6 means you 'strongly like' that country.

Finally, as noted, the survey also included a hypothetical question about military action under different circumstances in terms of international backing or alliances: 
Military action could be undertaken by Britain alone or in coalition with other countries. Under which of the following circumstances do you think it would be acceptable for Britain to take military action? (Please tick all that apply or, if you think military action would never be acceptable, choose 'none of these'.)

- As part of a United Nations operation

- As part of a European Union operation

- As part of a NATO operation (that is, with our closest North American and European allies)

- Along with the USA and its partners

- Acting alone

- None of these

\section{Results}

We present the results in three sections. First, we report responses to the hypothetical survey questions about international backing and support for action. Then, turning to the experiment, we analyse whether and how support depended on the manipulated factors. In the third section, we estimate more complex models testing for interactions between situational variables and predispositions.

Survey question on international backing

This question, about the conditions under which military action would be acceptable, was in a 'tick all that apply' format. The first column of data in Table II contains the percentages of respondents deeming action as acceptable in that case. These describe broadly the anticipated pattern: the wider the international coalition, the greater the support for action. The scale of the difference, a gap of around forty points between a UN coalition and acting alone, is consistent with results from opinion polls such as the one on Libyan action cited above. There is an obvious exception to this 'wider coalition equals stronger support' rule, however, which is that support from the USA does nothing to increase the perceived acceptability of the use of force. Respondents' reasoning can only be inferred but it seems highly likely that this reflects popular doubts about the legitimacy of recent US-led coalition action, notably in Iraq.

[Table II about here] 
The $72 \%$ support for participation in UN operations is notable for two reasons. First, it is only slightly (though statistically significantly) higher than the NATO figure, suggesting that most are satisfied with support from Britain's traditional allies and do not demand backing from those global powers - such as Russia or China - that have tended to withhold support. Second, it leaves $28 \%$ of people who would not approve of that most inclusive form of action. As the bottom row of the table confirms, these are not committed pacifists who renounce action regardless of circumstances - that was true of only $8 \%$ of the sample. In other words, most of those who rejected action with the UN supported action in at least one of the other circumstances.

This highlights a more general point that these responses are not hierarchically ordered as in a Guttman scale. Aside from the European Union (included in Table II for comparative purposes but not included in the experiment and therefore not of primary interest for this article), each option listed in the question is 'nested' in the previous option: that is, components are successively removed from the coalition but new elements are not added. It might be expected that everyone supporting action in a given circumstance would also support action under a wider coalition. That this is not the case is demonstrated by the matrix to the right of the table, in which we report the percentage of those saying 'yes' on the row variable that also said 'yes' on the column variable. If these responses approximated a Guttman scale, many of the proportions below the diagonal should approach $100 \%$. Most fall some way short. The most obvious case is that mentioned earlier concerning US support: not much more than half of those who support acting alone would also support participating in an American-led coalition. Yet one in six (17\%) of those who would act alone would actually reject participation in UN or NATO operations - these look like militant rather than cooperative internationalists. In addition, and belying the impression given by the basic percentages, support for UN and NATO missions does not come from more or less the same 
people. Only three-quarters $(76 \%)$ of those endorsing UN missions were also happy to see Britain working with NATO. These patterns do not imply any irrationality (of the kind sometimes inferred from intransitive preferences) on the part of respondents. Rather, they are testament to the complexity of the relationship between international backing and approval for military action. It is not (only) the extent but also the sources of support that drive public judgements.

Experimental results: i) situational factors

In Table III we show how approval of military action in defence of Country A differs across subgroups on the first three experimental variables. We use the dichotomous dependent variable in order to obtain simple percentages of support and use $\chi^{2}$ tests to identify any significant effects. The first column of data reports the overall breakdown while the panel to the right illustrates how these effects are moderated by the fourth experimental variable, the military strength of the adversary. ${ }^{12}$

\section{[Table III about here]}

The experiment offers clear support for $\mathrm{H} 1$ about passive support. Public support declines significantly along with international backing and the pattern of decline is quite similar. Although these results suggest that US involvement has at least some scope to boost public approval, the difference between the bottom two categories is not statistically significant. ${ }^{13}$ The most notable contrast between these results and those in Table II is that the overall effect of international support is weaker. This is consistent with the earlier argument that the strength of cues in hypothetical survey questions tends to magnify the effect of the

\footnotetext{
${ }^{12}$ The $\chi^{2}$ tests in the right-hand panel are of interaction terms from loglinear modelling of the three variables involved: adversary strength, the other experimental variable in question, and the dependent variable.

${ }^{13}$ Any difference could have less to do with the role of the US and more to do with the different wordings of the base category. 'Acting alone', as in the survey question, may suggest willingness to intervene where necessary, even if others fear to do so, whereas the experimental wording - 'has yet to win any significant international support' - implies that the international community has considered and dismissed the case for action.
} 
variable in question. Even this brief vignette introduces other contextual details that make passive support just one consideration in respondents' judgements.

There is also clear support for $\mathrm{H} 2$ about active backing. When British troops were a relatively small part of the total fighting force, respondents were markedly and significantly more supportive of action than when British forces were more or less acting alone. These results suggest that passive and active backing have similar impacts, with a 12- or 13-point gap between unilateral action and the most multilateral option. Of course, whether the effect sizes can be compared in this way depends on whether we achieved our aim in calibrating the two manipulations in parallel. Calibration is an inexact business but the similarity is noteworthy, as is the contrast between the strong and significant effect of troop percentages (relative contribution) and the non-significant effect of troop numbers (absolute contribution). This strong support for H3 looks unlikely to be a mere artefact of calibration. Finally, turning to the right-hand panel, we find some support for $\mathrm{H} 4$ - that international support is more important when the enemy is stronger - but only in the case of active support. Adversary strength has a predictable main effect - there is less public support for fighting a large and well-trained enemy - but does not appear to interact with passive backing. The general reluctance to undertake unilateral action did not melt away at the prospect of a relatively simple operation. However, there was a noticeable and significant interaction with relative troop contribution. If Britain was to supply only $10 \%$ of forces, the strength of the adversary had no appreciable impact on public approval, but the enemy's military capacity had quite a strong influence where Britain was to be fighting more or less alone. One interpretation of the difference is that passive support largely concerns the justification while active support largely concerns the effectiveness of military action, and adversary strength is factored into calculations of the latter but not the former. ${ }^{14}$

\footnotetext{
${ }^{14}$ There is little sign of an interaction between adversary strength and Britain's absolute contribution, further suggesting that troop numbers are not central to these calculations about effectiveness.
} 
Experimental results: ii) introducing predispositions

In order to introduce predispositions into the analysis, we turn to ANOVA using the alternative seven-point scale dependent variable. ${ }^{15}$ Before testing the interactive hypotheses H5(a)-(d), in Table IV we first report two models: the first includes only the experimental variables while predispositional controls are added in the second in order to allay suspicions that the experimental effects may be due to differences across groups in predispositions towards military action. The table includes F-statistics (and accompanying significance values) and partial eta ( $\eta)$, a measure of effect size. ${ }^{16}$

\section{[Table IV about here]}

Model 1 confirms the results from Table III. The only conclusion that needs any modifying is the suggestion that passive and active support have roughly equal impact. More formal measurements of effect size suggest that active support matters rather more (although this comes with the usual caveat about calibration of experimental manipulations). One other point worth noting about the effects of situational factors is the lack of any further significant interactions. In particular, there is no sign of any interaction between passive and active support. Rather than either being a sufficient or necessary condition for public support, their effects seem to be purely additive.

Model 2 shows that introducing the predispositional covariates leaves the core findings from the experiment unaffected. Predictably, many of these attitudinal variables have substantial main effects (and so $\mathrm{R}^{2}$ increases sharply). The influence of internationalism is particularly clear, markedly stronger even than those of respondents'

\footnotetext{
${ }^{15}$ The use of ANOVA is vindicated by the fact that responses to the dependent variable quite closely approximated a normal distribution (echoing the earlier point that few citizens are enthusiastically supportive of or flatly opposed to military action).

${ }^{16}$ We use $\eta$ rather than the more common $\eta^{2}$ because its interpretation is closer to that of standardised regression coefficients, and more mundanely because the higher values (avoiding a flood of zeros) ease comparison across effects and across models.
} 
general attitudes towards the use of force. Indeed, from the point of view of evaluating the experimental effect sizes, it is striking that the impact of active backing is as strong as that of respondents' beliefs about the justifiability of military action. This is another clear example of public judgements about war being shaped as much by the situation as by their predispositions.

However, our main interest in these predispositions is as moderators of the impact of international backing. We therefore estimated Model 2 from Table IV but adding interaction terms between international backing and each of the six predispositional variables. ${ }^{17}$ Including all of the interaction terms, many of them involving the same categorical variables, in the same model would have risked serious collinearity problems and so instead we estimate six versions of the expanded model, one for each predisposition in turn. To save space, we do not report estimates for all of the variables already dealt with in Table IV. Instead, each row in Table V represents a model and we just report the relevant interaction terms alongside the increase in $\mathrm{R}^{2}$ resulting from their inclusion.

\section{[Table V about here]}

The key result here is the shortage of significant interactions. Judging by the healthy sample size and the feeble effect sizes, this is not a case of multiple Type II errors. It seems instead that the impact of international backing on support for war is surprisingly consistent across the public. More specifically, there is no support for H5(c) or (d). Internationalists were more likely than isolationists to favour intervention, regardless of the circumstances. But the two types reacted in the same ways to

\footnotetext{
${ }^{17}$ Since we have no theoretical reason to suppose that attitudes to international actors would moderate the effect of active support (which in the vignette came from unnamed sources), our models omit those interactions.
} 
international support, either passive or active, showing the same relative reluctance to act alone but much greater willingness to intervene with support from the UN or NATO. ${ }^{18}$

The lack of support for H5(d) is even more striking. A vast amount of research in social and cognitive psychology leads us to expect that those with a positive view of an international actor should be disproportionately ready to take action alongside that organisation or state. Instead, even if respondents entered the experiment with a sharply critical view of the UN, they were just as likely to be prompted by UN backing into supporting military action. The same applies to NATO and the USA, the latter case particularly striking because it undermines any 'nonattitude' explanation for the null findings. Maybe prior attitudes to the international organisations had little moderating effect because they were top-of-the-head evaluations of unfamiliar organisations, but it is harder to believe that is true of the like-dislike ratings of the USA. We discuss this counter-intuitive findings further in concluding the article.

There is at least some support, albeit mixed, for H5(a) and (b). When it comes to passive backing, militarism can be added to the list of predispositions showing no interaction with situational variables. Whatever respondents' prior views on the justifiability or effectiveness of war, they reacted in the same way to the accumulation of moral support from partner states or organisations. However, these beliefs did moderate the effect of active backing. The two significant interaction effects are illustrated in Figure 1, which shows how the effect of Britain's share of troop contributions depends on prior beliefs about war. For the purposes of illustration, we separate groups 'low' and 'high' on each strand of militarism by dividing the two scales around their midpoint (and omitting those respondents choosing the

\footnotetext{
${ }^{18}$ Moreover, the curvilinearity hypothesis mentioned above - that international backing is less relevant for the most isolationist (who would oppose intervention anyway) and the most internationalist (who would favour intervention anyway) - can also be rejected. We split respondents into three groups of roughly equal size along the isolationism-internationalism dimension and re-estimated the model using that trichotomous variable as a factor. It had the expected powerful main effect but no significant interaction with either active or passive support.
} 
midpoint). The columns in the chart represent estimated marginal means in support for action. Error bars, denoting the $95 \%$ confidence interval for each estimated mean, are also included.

\section{[Figure 1 about here]}

These interactions are not especially strong - neither has a partial eta reaching $0.1-$ and so it is not surprising that, in Figure 1, they are overshadowed by the main effects of both variables (especially effectiveness). Nonetheless, there is a discernible and consistent pattern in line with H5(a) and (b). The extent of active support has only limited impact on those who regard force as hard to justify or not particularly effective anyway. It weighs more heavily in the judgements of those who are already more open to the military option. We can therefore echo the conclusion drawn by Herrmann et al. from their parallel analysis of militarism as a moderator of reactions to the context of war: 'militarists are not simply knee-jerk hawks who use force at every opportunity; rather, they are discriminating and...leaders cannot count on them to support the use of force if the interests at stake remain ambiguous' $(1999,563)$.

One final point to note is the lack of evidence supporting our earlier suggestion that passive support would be linked more closely to the justification of military action while active support would say more about its likely effectiveness. The two non-significant interactions for passive backing imply that this moral support was able to convince respondents across the board - that is, including some of those initially resistant to the use of force - of both the ethical and the practical case for military action. Equally, the two very similar patterns of interaction with active backing suggest that it was no more able to convince sceptics of the effectiveness than of the justification of military action.

\section{Conclusions}


Our primary aim in this study was to test whether the British people are happier for their government to take military action when such action has international backing. The point had so far mostly been assumed or inferred - here, we provide direct evidence that international support does translate into greater public support. This is not an especially surprising finding. Many other Western publics, notably in the US, have also been shown to favour multilateral action. In addition, our data were collected in the shadow of the Iraq war, by that point a highly unpopular engagement often criticised for a lack of international consensus and legitimacy. Indeed, perhaps the more surprising aspect of the results is the weakness of the international backing effects in our experiment. While our survey question - in line with other surveys (e.g. Isernia \& Everts, 2004) and polls - found a huge gap of 41 points between support for participating in a UN operation and support for acting alone, the corresponding experimental difference was just 13 points. Almost half of the sample approved unilateral action in the case described in the vignette. Perhaps, in practice, the British public might turn out to be rather less multilateral than has been supposed.

This conjecture raises the question of the external validity of the experimental results. We would argue that they are more valid than hypothetical survey questions in which international backing is the only cue provided. Indeed, since our vignette includes only a fraction of the contextual detail that would be involved in a real-world situation, it could be argued that even those subtler cues are still unrealistically prominent. The impact of international backing could in practice be even weaker. On the other hand, in public discourse about military action, the extent of international support will be not just mentioned but thoroughly discussed. It may be that, once the reasons for and implications of a lack of backing are threshed out, the public becomes more responsive to that aspect of the situation.

That point, about the implications of (a lack of) international backing, in turn raises an issue of internal validity. Sher and McKenzie (2006) note the possibility in experiments of 
'information leakage', whereby respondents infer additional information beyond that which is explicitly cued in the manipulation. In that event, we do not know whether it is international backing or the inferences drawn from it that drive the dependent variable. Where British troops were to make up $90 \%$ of the total, for example, respondents may have turned against action not because the lack of support made it appear unjustified or futile, but because they resented the 'free riding' by the rest of the international community. In a similar vein, the experiment cannot fully elucidate why respondents - many of whom will have only a hazy idea of what the UN and NATO are and do - were nonetheless influenced by support from these organisations. None of this undermines our core findings, however. While it would be interesting to identify the routes via which the public goes from international backing to support for military action, it would not alter our conclusion about the initial cause and ultimate effect.

Moreover, our design, with manipulations of both active and passive backing, will have helped to plug what would otherwise have been substantial leakage between the two (with respondents considering the practical implications of a lack of passive support or the normative implications of having to send in troops alone). We can therefore have more confidence in the conclusion that active backing had a somewhat stronger effect on public support. It seems that some respondents wondered what was the use of moral support if British troops were still left to take action on their own. The point should not be overstated, since both dimensions of international backing influenced opinion - an experimental corroboration of Eichenberg's (2006) aggregate poll analysis. Nonetheless, these results suggest a 'pretty prudent' public, seeking multilateralism less for its own sake and more for what it implies about the costs and benefits of British participation.

Probably the most surprising aspect of the results was the consistency of international backing effects. The effect of passive support was uniform across people with widely 
different prior attitudes to military action, international engagement, and the particular international actors involved. Herrmann et al. (1999), while more successful in identifying predispositional moderators of contextual effects, also note that a number of such interactions did not emerge. They concluded that there are certain key features of a military scenario that weigh in public judgements across the board. Judging by our results, international backing and passive backing in particular - can be added to the list of such features. Even active backing, although it had less power to sway those who were predisposed against military action, did at least cause some softening of opposition. All of this only goes to reinforce the point that very few people are staunchly pacifist or zealously militarist. For the large majority of the public, judgements about the use of force are a matter of balancing predispositions with strategic calculations based on the context. 


\section{References}

Almond, Gabriel (1950) The American People and Foreign Policy (New York: Harcourt).

Alvarez, R. Michael \& Brehm, John (2002) Hard Choices, Easy Answers (Princeton, NJ: Princeton University Press).

Bronski, Michael J. \& Way, Christopher R. (2003) Does John Bull rally 'round the Union Jack? The nature of the "rally "round the flag" effect in the United Kingdom, 1950-2000. Unpublished manuscript, Cornell University.

Chapman, Terrence L. \& Reiter, Dan (2004) The United Nations Security Council and the 'rally round the flag' effect. Journal of Conflict Resolution, 48(6), 886-909.

Clarke, Harold D., Mishler, William \& Whiteley, Paul (1990) Recapturing the Falklands: Models of Conservative popularity 1979-1983. British Journal of Political Science, 20(1), 63-81.

Clements, Ben (2013), Public Opinion and Military Intervention: Afghanistan, Iraq and Libya. Political Quarterly, 84(1), 119-31.

Converse, Philip E. (1964) The nature of belief systems in mass publics, in: David Apter (ed) Ideology and Discontent (New York: Free Press), 206-69.

Dixon, Paul (2000) Britain's 'Vietnam syndrome'? Public opinion and British military intervention from Palestine to Yugoslavia. Review of International Studies, 26(1), 99-121.

Eichenberg, Richard C. (2006) Global public opinion on the use of military force from the first Gulf War to the invasion and occupation of Iraq. Paper presented at the Annual Convention of the International Studies Association, San Diego, CA, 22-26 March.

Gartner, Scott Sigmund \& Segura, Gary M. (1998) War, casualties and public opinion. Journal of Conflict Resolution, 42(3), 278-300.

Gartzke, Erik (2000) Preferences and the Democratic Peace. International Studies Quarterly, 44(2), 191-210.

Herrmann, Richard K., Tetlock, Philip E. \& Visser, Penny (1999) Mass public decisions to go to war: A cognitive-interactionist framework. American Political Science Review, 93(3), 553-73.

Herrmann, Richard K., Isernia, Pierangelo \& Segatti, Paolo (2009) Attachment to the nation and international relation: Dimensions of identity and their relationship to war and peace. Political Psychology, 30(5), 721-54.

Holsti, Ole R (2004) Public Opinion and American Foreign Policy (Ann Arbor: University of Michigan Press).

Holsti, Ole R. \& Rosenau, James N. (1993) The structure of foreign policy beliefs among American opinion leaders after the Cold War. Journal of International Studies, 22(2), 235-78.

Hurwitz, Jon \& Peffley, Mark (1987) How are foreign policy attitudes structured? American Political Science Review, 81(4), 1099-1120.

Isernia, Pierangelo \& Everts, Philip P. (2004) Partners apart? The foreign policy attitudes of the American and European publics. Japanese Journal of Political Science, 5(2), 229-58.

Jentleson, Bruce W (1992) The pretty prudent public: Post-Vietnam American opinion on the use of military force. International Studies Quarterly, 36(1), 49-73.

Johns, Robert and Davies, Graeme A. M. (2012) Democratic peace or clash of civilisations? Target states and support for war in Britain and the USA. Journal of Politics, 74(4), 103852.

Kadera, Kelly M., Crescenzi, Mark J. \& Shannon, Megan (2003) Democratic survival, peace and war in the international system. American Journal of Political Science, 47(2), 224-47.

Kam, Cindy D. \& Kinder, Donald R. (2007) Terror and ethnocentrism: Foundations of American support for the war on terrorism. Journal of Politics, 69(2), 320-38. 
Karol, David \& Miguel, Edward (2007) Iraq War casualties and the 2004 U.S. Presidential election. Journal of Politics, 69(3), 633-48.

Kull, Steven \& Destler, I. M. (1999) Misreading the Public: The Myth of a New Isolationism (Washington, DC: Brookings).

Lai, Brian, and Reiter, Dan (2005) Rally round the Union Jack? Public opinion and the use of force in the United Kingdom, 1948-2001. International Studies Quarterly, 49(2), 255-72.

Morton, Rebecca B., \& Williams, Kenneth C. (2008) Experimentation in political science, in: Janet M. Box-Steffensmeier, Henry E. Brady, and David Collier (eds) Oxford Handbook of Political Methodology (Oxford: Oxford University Press), 339-56.

Oneal, John R., Lian, Bradley, and Joyner Jr., James (1996) Are the American people 'pretty prudent'? Public responses to U.S. uses of force, 1950-1988. International Studies Quarterly, 40(2), 261-79.

Page, Benjamin I. \& Barabas, Jason (2000) Foreign policy gaps between citizens and leaders. International Studies Quarterly, 44(3), 339-64.

Price, Simon \& Sanders, David (1993) Modeling government popularity in post-war Britain: A methodological example. American Journal of Political Science, 37(1), 317-34.

Reifler, Jason, Scotto, Thomas J. \& Clarke, Harold D. (2011) Foreign policy beliefs in contemporary Britain: Structure and relevance. International Studies Quarterly, 55(1), 245-66.

Reiter, Dan (2003) Exploring the Bargaining Model of War. Perspectives on Politics, 1(1), 117.

Russett, Bruce (1993) Grasping the Democratic Peace (Princeton: Princeton University Press).

Russett, Bruce, Hartley, Thomas \& Murray, Shoon (1994) The end of the Cold War, attitude change and the politics of defense spending. PS: Political Science \& Politics, 27(1), 17 21.

Sanders, David, Clarke, Harold D., Stewart, Marianne C. \& Whiteley, Paul (2007) Does mode matter for modeling political choice? Evidence from the 2005 British Election Study. Political Analysis, 15(2), 257-85.

Sher, Shlomi \& McKenzie, Craig R. M. (2006) Information leakage from logically equivalent frames. Cognition, 101(3), 467-94.

Smith, Hugh (2005) What costs will democracies bear? A review of popular theories of casualty aversion. Armed Forces \& Society, 31(4), 487-512.

Sniderman, Paul M., Brody, Richard A., and Tetlock, Philip E. (1991) Reasoning and Choice: Explorations in Political Psychology (Cambridge: Cambridge University Press).

Sullivan, Patricia L. (2008) Sustaining the fight: A cross-sectional time-series analysis of public support for ongoing military interventions. Conflict Management and Peace Science, 25(2), 112-35.

Todorov, Alexander \& Mandisodza, Anesu N. (2004) Public opinion on foreign policy: The multilateral public that perceives itself as unilateral. Public Opinion Quarterly, 68(3), 323-48.

Wittkopf, Eugene R (1990) Faces of Internationalism: Public Opinion and American Foreign Policy (Durham, NC: Duke University Press).

Younger, Kenneth (1964) Public opinion and British foreign policy. International Affairs, 40(1), 22-33.

Zaller, John R (1992) The Nature and Origins of Mass Opinion (New York: Cambridge University Press). 


\section{Table I}

\section{Methodological details of the surveys}

\begin{tabular}{|l|l|c|l|}
\hline Wave & $\begin{array}{l}\text { Fieldwork dates } \\
\text { [responses in first } \\
\text { two days] }\end{array}$ & $\mathrm{N}$ & $\begin{array}{l}\text { Response rate } \\
\text { [denominator] }\end{array}$ \\
\hline $\begin{array}{l}1-\text { hypothetical questions; militarism; } \\
\text { internationalism }\end{array}$ & $\begin{array}{l}\text { 18-19 Jan 2010 } \\
{[100 \%]}\end{array}$ & 2,615 & $\begin{array}{l}61 \% \\
\text { [contacts] }\end{array}$ \\
\hline $\begin{array}{l}2-\text { survey experiment; psychological } \\
\text { controls }\end{array}$ & $\begin{array}{l}1-8 \text { Feb 2010 } \\
{[91 \%]}\end{array}$ & 2,205 & $\begin{array}{l}85 \% \\
{[\text { Wave 1 respondents] }}\end{array}$ \\
\hline $\begin{array}{l}3-\text { attitudes to international } \\
\text { organisations }\end{array}$ & $\begin{array}{l}15-22 \text { Feb 2010 } \\
{[86 \%]}\end{array}$ & 2,065 & $\begin{array}{l}81 \% \\
\text { [Wave 1 respondents] }\end{array}$ \\
\hline
\end{tabular}

${ }^{19}$ Since members of the opt-in YouGov panel do not have a known probability of selection, it is not feasible to calculate a response rate taking into account all sources of non-response, including panel recruitment and retention. Here, then, response rates are in effect completion rates, representing the proportion of those asked to take part in that survey that agreed to do so. 


\section{Table II}

Acceptability of military action with different levels of international backing $(\mathrm{N}=2,202)$

\begin{tabular}{|c|c|c|c|c|c|c|}
\hline & & \multicolumn{5}{|c|}{$\%$ of these also endorsing action with... } \\
\hline \multicolumn{2}{|c|}{$\%$ endorsing action with... } & $\mathrm{UN}$ & NATO & EU & USA & Alone \\
\hline UN & 72 & -- & 76 & 57 & 36 & 37 \\
\hline NATO & 67 & 81 & -- & 59 & 40 & 40 \\
\hline EU & 54 & 89 & 87 & -- & 49 & 46 \\
\hline USA & 30 & 84 & 88 & 73 & -- & 59 \\
\hline Alone & 31 & 83 & 83 & 66 & 56 & -- \\
\hline None of these & 8 & -- & -- & -- & -- & -- \\
\hline
\end{tabular}


Table III

Support for action by international backing: overall and by adversary military strength

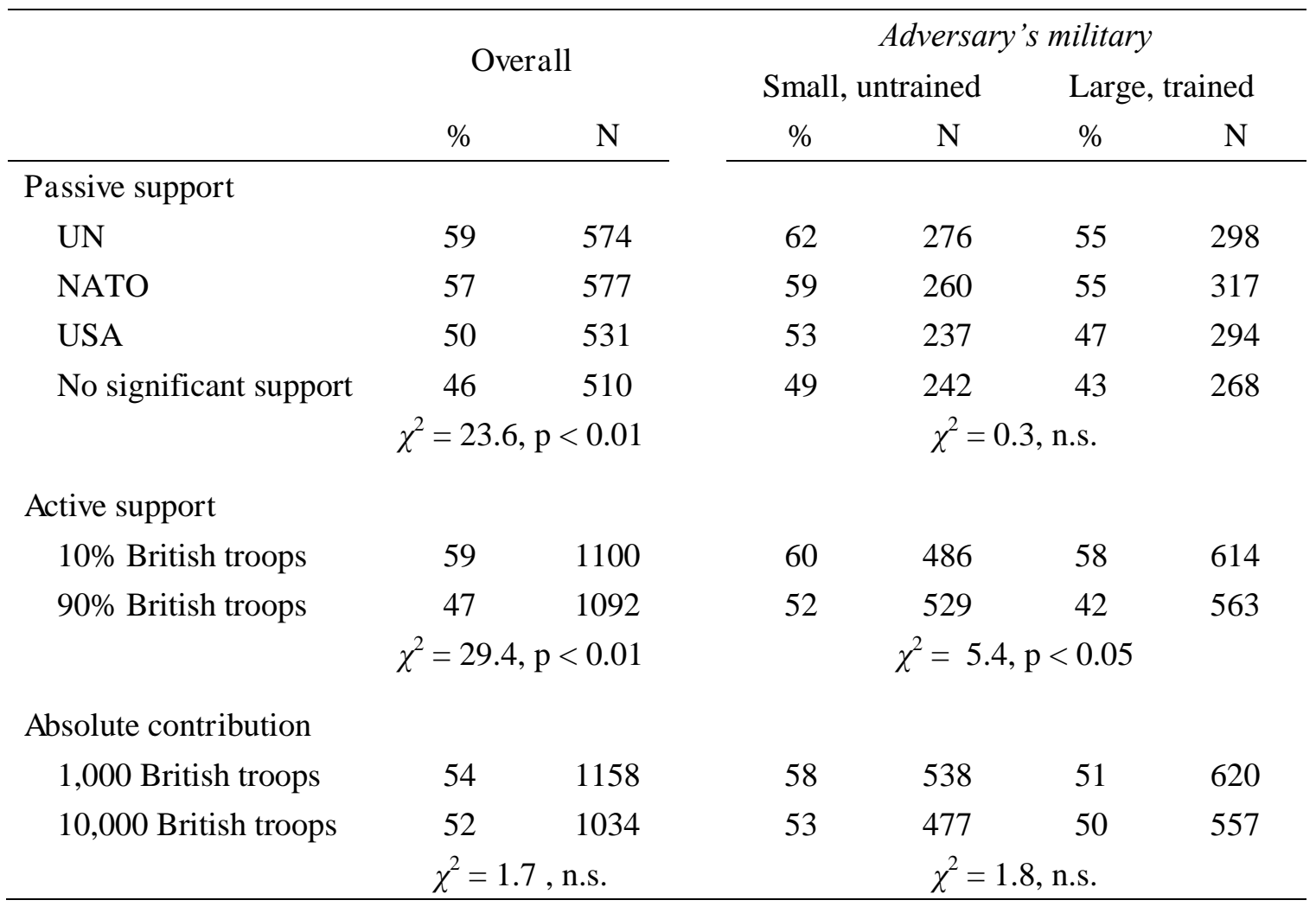


Table IV

ANOVA in support for action by situational manipulations and predispositions

\begin{tabular}{|c|c|c|c|c|c|}
\hline & & \multicolumn{2}{|c|}{ Model 1} & \multicolumn{2}{|c|}{ Model 2} \\
\hline & & $\mathrm{F}$ & $\eta$ & $\mathrm{F}$ & $\eta$ \\
\hline \multicolumn{2}{|l|}{ Support (passive backing) } & $7.9 * * *$ & 0.10 & $11.1 * * *$ & 0.13 \\
\hline \multicolumn{2}{|l|}{$\%$ of troops (active backing) } & $61.2 * * *$ & 0.17 & $76.1 * * *$ & 0.19 \\
\hline \multicolumn{2}{|l|}{ Number of troops } & 2.5 & 0.03 & 0.9 & 0.02 \\
\hline \multicolumn{2}{|l|}{ Adversary strength } & $7.6^{* *}$ & 0.06 & $4.4 * *$ & 0.05 \\
\hline \multicolumn{2}{|l|}{ Support $* \%$ of troops } & 0.2 & 0.02 & 0.5 & 0.03 \\
\hline \multicolumn{2}{|l|}{ Support * no. of troops } & 0.6 & 0.03 & 0.6 & 0.03 \\
\hline \multicolumn{2}{|l|}{ Support $*$ adversary } & 0.7 & 0.03 & 0.8 & 0.03 \\
\hline \multicolumn{2}{|l|}{$\%$ of troops $*$ no. of troops } & 0.1 & 0.01 & 0.2 & 0.01 \\
\hline \multicolumn{2}{|l|}{$\%$ of troops $*$ adversary } & $9.1 * * *$ & 0.06 & $8.2 * * *$ & 0.06 \\
\hline \multicolumn{2}{|l|}{ No. of troops $*$ adversary } & 0.1 & 0.01 & 0.5 & 0.02 \\
\hline \multicolumn{2}{|l|}{ Force justified } & & & $76.2 * * *$ & 0.19 \\
\hline \multicolumn{2}{|l|}{ Force effective } & & & $98.7 * * *$ & 0.21 \\
\hline \multicolumn{2}{|l|}{ Internationalism } & & & $184.4 * * *$ & 0.28 \\
\hline \multicolumn{2}{|l|}{ Respect UN } & & & $6.1 * *$ & 0.05 \\
\hline \multicolumn{2}{|l|}{ Respect NATO } & & & $21.3^{* * *}$ & 0.10 \\
\hline \multirow[t]{3}{*}{ Like/dislike USA } & & & & 0.5 & 0.02 \\
\hline & $\mathrm{R}^{2}$ (adj.) & \multicolumn{2}{|c|}{0.05} & \multicolumn{2}{|c|}{0.30} \\
\hline & $\mathrm{N}$ & \multicolumn{2}{|c|}{2201} & \multicolumn{2}{|c|}{2061} \\
\hline
\end{tabular}


Table V

Interactions between international backing and predispositions in ANOVA models of support for action

\begin{tabular}{|c|c|c|c|c|c|c|}
\hline \multirow[b]{2}{*}{ Interaction with... } & \multicolumn{2}{|c|}{ Passive backing } & \multicolumn{2}{|c|}{ Active backing } & \multirow[b]{2}{*}{$\uparrow R^{2}$} & \multirow[b]{2}{*}{$\mathrm{N}$} \\
\hline & $\mathrm{F}$ & $\eta$ & $\mathrm{F}$ & $\eta$ & & \\
\hline Use of force generally justified & 1.0 & 0.03 & $9.0 * * *$ & 0.07 & 0.004 & 2201 \\
\hline Use of force generally effective & 1.4 & 0.04 & $11.7 * * *$ & 0.08 & 0.008 & 2201 \\
\hline Internationalism & 1.3 & 0.04 & 0.3 & 0.01 & 0.003 & 2201 \\
\hline Respect for UN & 0.5 & 0.02 & -- & -- & 0.001 & 2061 \\
\hline Respect for NATO & 1.0 & 0.04 & -- & -- & 0.002 & 2061 \\
\hline Like/dislike USA & 0.8 & 0.03 & -- & -- & 0.001 & 2061 \\
\hline
\end{tabular}




\section{Figure 1}

Mean support for action by active support and prior beliefs about war

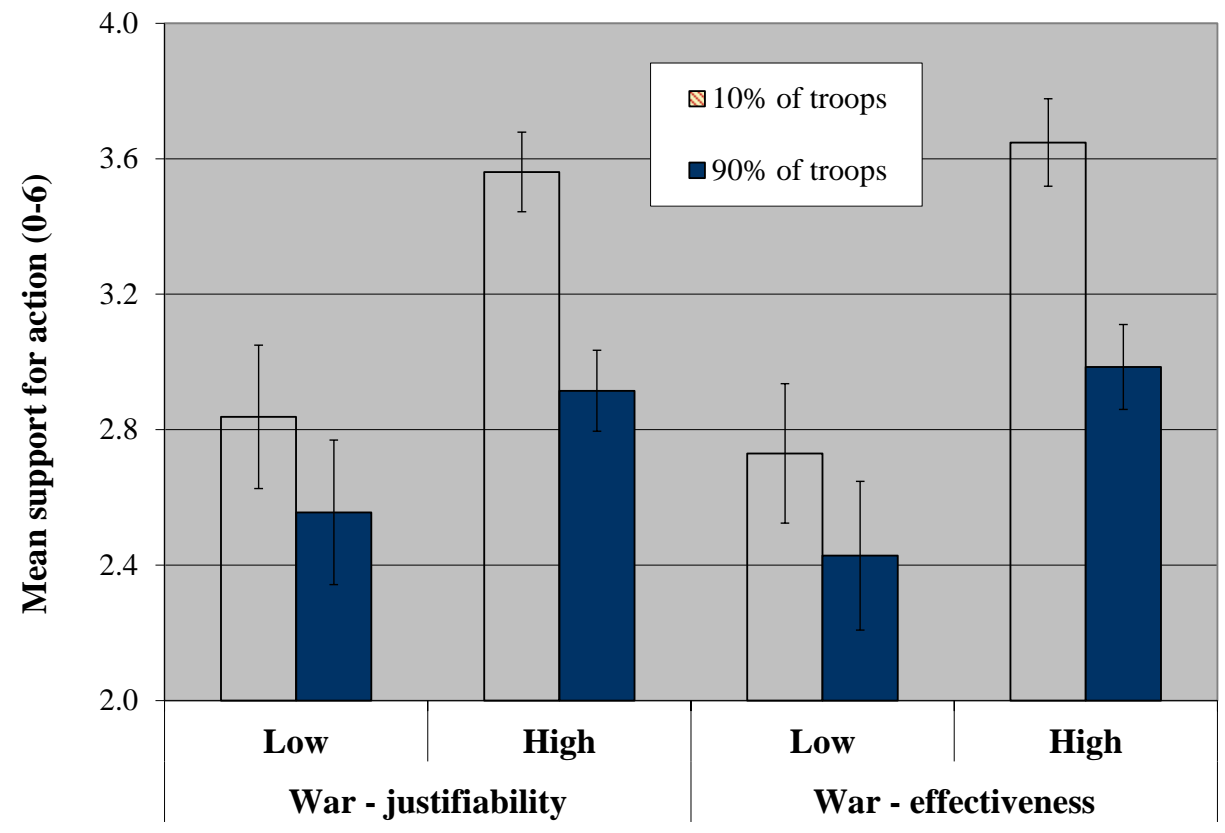

